\title{
Preschool, Multilingualism and Translanguaging_-Linguistic Diversity, Language Strategies and Participation
}

\author{
Ann-Christin Torpsten \\ Department of Pedagogy, Linnaeus University, Kalmar, Sweden
}

\begin{abstract}
This text focuses on multilingual children's education and language development in the Swedish preschool context discussing linguistic strategies, language diversity, native language, and native language support. Speaking Swedish in the Swedish preschool is the norm; it is the major language in Sweden and it is also the native language of the majority of the children. However, speaking about native language in the Swedish school context, it is often about native languages other than Swedish. We are speaking about the children with a native language other than Swedish, the multilingual children. Research shows that interaction between the children and the teachers is crucial for the children's learning, language acquisition, and identity development. The interaction, expectations, and attitudes that the child, the teacher, and others in the surroundings have both to the language or languages that should be learned and to the child who should learn, are also critical for success in language development. When a child in the preschool pedagogical practice develops the native language, the child becomes less subordinate, can play together in many settings, and get access to the world in the preschool and in the society that is expressed and understood through language.
\end{abstract}

Keywords: preschool, translanguaging, linguistic diversity, language norm, language development

\section{Introduction}

When we speak about the pedagogical context in the Swedish preschool, it is often about the preschool's tasks, the child's perspective and relationship to societal values, and equality for all children. We also discuss the children's development and learning, and that the teachers in preschool have the responsibility to interpret, adapt and, convey the values formulated in the preschool policy documents. We can read in the preschool curriculum that much emphasis is placed on people and the ability to understand the values inherent in diversity (National Agency for Education, 2011). We can also read that fostering equality and democracy is just as important as language, learning, and identity formation taking place together (National Agency of Education, 2010; 2012). There is support for this in research, such as, that children with foreign backgrounds who develop their native language have both better opportunities to learn Swedish and opportunities to develop skills in several languages, namely, multilingual competence. This promotes learning also in other areas (Cummins \& Schecter, 2003; Hyltenstam \& Tuomela, 1996; Lindberg, 2002; National Agency for Education, 2011). Those children both preserve and develop their native language and cultural identity, which becomes a part of their civic education that benefits both the individual and society (Benhabib, 2004a). However, it is not only the children with a native language other than Swedish who have a chance to develop skills in the preschool

Ann-Christin Torpsten, associate professor, Ph.D., Department of Pedagogy, Linnaeus University. 
practice. Knowledge of one's own and of other children's cultural heritage contributes to all children being able to develop their ability to understand and experience other children's different circumstances and values (National Agency for Education, 2011).

Speaking Swedish in preschool is the norm; it is the major language in Sweden. Thus Swedish is necessary in order to be able to participate fully in preschool. The Swedish language is also the native language of the majority of the children. However, when we speak about native language in the Swedish school context, it is often about native languages other than Swedish. We are speaking about the children with a native language other than Swedish who are multilingual children. These children learn Swedish as a second language. We are aware that children with a native language other than Swedish and multilingual children do not constitute a homogenous group, neither do all the children who have Swedish as their native language. All children have their experiences and skills with language, but we sometimes speak about children as if it were possible to categorize them into homogenous groups, like the multilingual children, the children who receive native language support, or the children with foreign background.

The above discussion forms the basis for the present paper, the purpose of which is to direct focus on multilingual children's education and language development in preschool. I discuss linguistic strategies, language diversity, native language, and native language support. By native language support and native language instructors, I mean support in the development of native languages other than Swedish and the native language instructors who support the children's language development in a native language within the preschool pedagogical practice.

\section{Linguistic and Cultural Diversity in Preschool}

Many of the children who are enrolled in Swedish preschools are multilingual and have Swedish as their second language. The Ministry for Education and Research (2006) shows that over $20 \%$ of preschool children have a foreign background. Thus the Swedish preschool and its activities emerge as an arena where linguistic and cultural diversity are possible. The preschool acts as a cultural meeting place and a stage for the children's future life in a global context. For children with a native language other than Swedish, it is in the preschool that opportunities can be created to develop the ability to communicate in both their native language and Swedish. For children with Swedish as their native language, it is in the preschool that opportunities can be created to develop the ability to communicate in both their native language and in the second language. An ability to switch between languages according to what different situations require, is like an individual's skill to perform in different arenas, according to Petersson and Åhlund (2007a, 2007b).

Because people move around, cross-border cultures and cultural and linguistic variation become more common; increased mobility in turn leads to many young people becoming multilingual (Cummins \& Schecter, 2003). In the preschool pedagogical practice, all children can be prepared to participate in an increasingly global society (National Agency for Education, 2011).

\section{Human Mobility and Foreign Background in Historical Perspective}

That people are mobile and move from to Sweden has a long tradition. At the beginning of the $1900 \mathrm{~s}$, a quarter of Sweden's population had emigrated, mainly to America and Australia. The population movement changed direction during the World Wars when immigration to Sweden was larger than the emigration. In the 1950s and 1960s, there was a great demand for labor in Swedish industry and people arrived from such 
countries as Finland, former Yugoslavia, and from other European countries in order to find work. In the late 1970s, people often fled from countries outside Europe to Sweden in order to seek protection. It was no longer labor migrants, but refugees or immigrants who already had relatives in Sweden. Early in the first decade of 2000, we knew that people fleeing war and persecution sought for refuge in Sweden. The proportion of foreign-born during the 1940 s was about $1 \%$ and in 1970 there was almost $7 \%$ born in a country other than Sweden. At the end of the 1990s, just over ten percent of the population was foreign-born (Ekberg \& Rooth, 2000).

When people move between countries, it also means that children move. For the preschool and compulsory school in the first years of the new millennium 2000, it means that the proportion of children with foreign background is just over one-fifth of all children.

\section{Equality, Freedom of Choice and Interaction}

Immigration to Sweden was regulated when Parliament formulated the immigrant and minority policy goals on equality, freedom of choice and interaction (Prop. 1975:26; SOU, 1974:69). Through the immigration policy goals of 1977 (Prop. 1997/98:16), mutual respect, integration and societal diversity were particularly stressed. The concept of diversity encompassed class, gender, ethnicity, age, and religion. The goal of equality meant equal living conditions and rights for all, the same rules regardless of whether or not one is an immigrant, and education in both Swedish and the native language. It also meant information about the Swedish society. The goal of freedom of choice meant being able to choose oneself to what extent one would integrate into the Swedish cultural identity and to maintain and develop one's original culture and identity. The goal of interaction involved cooperation among the majority population, the immigrants and minority groups, mutual respect, and solidarity. The minority groups were equal parties in society who were engaged in societal issues and participating in the society's development. Other objectives of the interaction were education and information for understanding among people with different origins.

The education goals apply to both adults and children and the education is controlled by the national curriculum where in writing it is established what is important to learn to be able to function in society. The education and instruction intended for immigrants' children, for children with foreign background, and for all children in preschool, are thus covered by one nationally-regulated education which has the aim to be equal.

\section{Native Language and Native Language Support in Preschool}

In a government proposal to Parliament in 1968, special initiatives were stated for immigrant children's education which involved collaboration between the school and home in order to promote all children's harmonious development and their opportunities to establish themselves in Sweden on equal terms. Immigrant children's needs for special support interventions are also formulated in the Children's Preschool Review (SOU, 1972:26-27) and are then expressed as the children's needs regarding language, communication, and adaptation. When the immigrants' children should adapt to the Swedish culture and acquire the Swedish language and the Swedish preschool represented the norm. With the preschool and special support interventions, the immigrants' children could be introduced to the Swedish school culture and be prepared for school. In playing with the Swedish-speaking children, the immigrants' children could acquire the school language in order to be able to reach the same language level in Swedish as their Swedish-speaking friends by the time school started. In this way, the education conditions should be equal. 
The society's and the school's responsibility to support the development of children's and young people's bilingualism became law in 1976/1977 through the home language reform. The reform set goals for the instruction of immigrant children in compulsory school and for language instruction for pupils with immigrant background in the form of home language lessons and home language support in preschool (Government Council, 1975). The label "home language" was changed in 1977 to "mother tongue" in order to situate the subject in a broader societal perspective. At the same time, the instructors' education in multi-cultural competence became important in order to be able to meet children from different cultures, that is to say, cultures other than Swedish. It should be possible in preschool for children to develop an affiliation both with their own families, namely, their home culture and language and with the Swedish culture and language represented by the preschool.

The discussion above shows us that the instructional interventions have been directed towards resolving the immigrant children's needs regarding adaption, communication, and introduction to school. It also shows that a new mother tongue subject has been developed in order to facilitate these children's development of bilingualism. Instruction, guidance, and support in a native language other than Swedish have been in Swedish schools and preschools for almost 40 years. A native language, other than Swedish, is its own subject; and Swedish, as the native language, is another subject. Both have their own syllabus. Since 1994, pupils also have had the opportunity to choose their native language as a language choice or as the pupil's choice for the school alternative as a native language outside the regular school schedule. This discussion also shows the one-directional approach in the policies about equal education conditions, because there are no statements expressing that the Swedish-speaking children, in playing with the immigrants' children, can acquire multiple languages.

\section{Preschool and the Role of Native Language Instructor}

In the preschool curriculum (National Agency for Education, 2008, 2011), we can read that when children with a native language other than Swedish are offered native language support in preschool, their fundamental language skills in both their native language and the Swedish language can be developed. We can also understand that the native language support instructors can stimulate and support the children's language development in a special way so that both their development of multilingualism and of multi-cultural identity become easier. In preschool, it is therefore important that children develop an interest and curiosity for written language. Together with the other preschool staff, children and parents, the native language instructors can plan, carry out, and develop the language development support. From the curriculum text, we can also understand that the early support interventions bring gains for both the children and society.

\section{Multi-literacy Competence_-From Monolingual to Translanguaging}

Cummins (2007) emphasizes that teachers mainly base their second language instruction of multilingual pupils on three language strategies: The target language is the only language used in the classroom and translation between Language 1 and Language 2 does not occur, and the pupils' Language 1 and Language 2 are treated as completely separate, which for instruction in the Swedish school means that instruction of Swedish as a second language and as a native language are distinguished. The concept translanguaging was coined by Cen Williams (1994) who demonstrated that strategic collaboration between the pupils' first and second languages in the classroom led to improvements in both the pupils' languages as well as deepened 
subject knowledge. Cummins (2007), Cummins and Persad (2014), Garcia (2012), and Creese and Blackledge (2010) show that instruction that builds up on the pupils' previous linguistic experiences promotes identity and knowledge development in school.

\section{Native Language Support and Positive Consequences}

Research shows that native language instructors especially emphasize native language support in preschool and its importance (Torpsten \& Betzholtz, 2013). According to native language instructors, the children's opportunities for development of multilingualism increase when they receive native language support in preschool and it gives positive consequences for success in school.

In the short term, it is the native language that is favored, but the children are going to be grateful when they become bi/trilingual adults. Very sure that it helps to perceive and understand what the teachers have to offer at school. (Torpsten \& Betzholtz, 2013, p. 8)

In the near perspective, the native language benefits the most, but the development of the native language and Swedish go hand in hand. The native language instructors believe that when the children become adults, they will appreciate that they are bilingual. They also reveal that good cooperation between the different groups of instructors is good for the children and that native language instructors function as support for the other instructors who desire that. The cooperation with and support of native language instructors can mean various kinds of advice, such as tips on books for reading aloud to all children and for individual children (ibid.).

In a language supportive approach, the school librarians appear as significant persons and the school libraries as important places for all children and educators, especially when it comes to all children's understanding of the great value of cultural diversity and awareness of different languages and their ability to experience other children's different circumstances (National Agency for Education, 2011). However, in order to get to know and be able to understand others' circumstances and values through reading, there must be books for children in different native languages, both in Swedish and in other languages, and also on different cognitive levels. There must be also books that arouse different children's various interests. For example, either with an adult's assistance or on their own, the children can read aloud in their respective native languages from children's books or children's magazines that the children themselves have chosen. In this way, all children can take part in the linguistic diversity. All the children perhaps do not understand what is read aloud, but with the native language instructor's help, one can tell the story afterwards. One problem that can arise in this context is that the school library with its book collection does not meet the need for children's books from different countries in various languages. The school library probably primarily contains children's literature in Swedish that deals with Sweden, Swedish relationships, and Swedish children.

However, there are good examples of school librarians who work with a language supportive approach. I refer here to Ahlstedt (2014) who presents school librarians of world class and their language and identity supportive work in a multicultural school.

\section{Native Language Support at a Disadvantage}

The roles of native language supporter and native language instructor are not always simple (Svensson \& Torpsten, 2013; Torpsten \& Betzholtz, 2013). It seems difficult to be a native language instructor and that regards both the preschool and the compulsory school. One difficulty may be that there is no regulated teacher 
training for native language instructors and native language supporters in accordance with the Ministry of Education guidelines. Another problem can be that the education programs that are organized are of varying quality and they are organized differently at different colleges and universities. Having teacher training is not even required to be employed as a native language instructor or native language supporter. Native language instructors and supporters can have other pedagogical and subject-related education and long experience, but the employment is not permanent but unstable. It turns out that native language instructors and native language supporters thus have difficulties qualifying as teachers and difficulties asserting themselves in the school's pedagogical practice (Svensson \& Torpsten, 2013). These problems can for example be due to the instruction or support in the native language arranged in the late afternoon or at another school so that the children have to go to a school other than their own. This can also mean that the native language teachers travel among several preschools or schools, that they are not included in the different schools' work teams, and that their work schedule is organized last when all the other schedules are established. When the native language instructors travel among several schools every day, it can happen that they arrive at preschools when the children are sleeping, which no one experiences positively. It is also not positive when the native language instructors perceive that there are many children who need support, but there is not enough time.

Research also reveals a negative attitude and lack of understanding for native language support which has not been prioritized in the preschool practice. Other categories of teachers have acknowledged neither why native language supporters come to preschool (Torpsten \& Betzholtz, 2013) nor the significance of native language support in the Swedish-speaking preschool context. Teachers judge this cultural delineation as an asset when it is practical and when it is as a cultural buffet where one can choose what one tries or refrains from trying. This attitude may seem both compulsory and prohibitive for children. When/if the linguistic and cultural diversity are made invisible within the preschool pedagogical practice, it becomes difficult to realize the preschool's cultural, linguistic, and identity development tasks (Lunneblad, 2006; Runfors, 2003).

\section{Language, Learning and Identity Development}

Encountering the preschool language can mean for a child meeting a new linguistic practice. It can be likened to meeting a new language arena where the child's understanding of the world is changed (see Petersson \& Åhlund, 2007). When the child learns a new language and wonders about her friends' using different languages, she has changed position in her language room and widened her linguistic perspective. Research (Cummins \& Schecter, 2003; Petersson \& Åhlund, 2007a, 2007b) shows that children who have the opportunity to create hybrid linguistic and cultural competences can be active in several arenas, both on the individual and the societal levels. Mastering a diverse language competence becomes an advantage; it becomes a supplement that makes it possible to participate in various contexts. In an earlier study (Torpsten, 2008), I showed that the use and development of native language also became a way to experience affiliation with related preserved memories.

...it was only when I acquired good language skills in (my native language) and Swedish that I became aware of how often I switch between languages and the way I speak, depending on the situation. But when I talk to Mom, then it is (my native language); there is more affinity. (Torpsten, 2008, p. 119)

When the children in preschool have access to native language instructors who speak the same language as the children's parents, their identities are also strengthened (Torpsten \& Betzholtz, 2013). With the multilingual 
competence, it also becomes possible for the children to make both conscious and unconscious identity changes. "It is based on this language switching that I assume different roles depending on the situation and the individuals I meet" (Torpsten, 2008, p. 152). When it becomes possible for the children in the multilingual preschool practice to choose between speaking their native language and speaking Swedish, the children can also choose the identity of being multilingual.

On the preschool language stage, many different languages can appear. And when the children in preschool socialize with friends who speak different languages, they develop competence in several languages. These multilinguistic competencies continue to develop when the children play, speak, read, and write together with each other. But children also learn language through instruction or support, and the best result is in environments where the children feel accepted and experience that they are part of the peer community. In addition to the acceptance for language diversity in the preschool pedagogical practice, it means the children can be included in both a Swedish-speaking community and a native language-speaking community.

Researchers (Cummins \& Schecter, 2003; Cummins, 2006) who have studied teachers' ways of interacting with multilingual children, also establish that the interaction between the children and the teachers is crucial for the children's learning, language acquisition, and identity development. The interaction, expectations, and attitudes that the child, the teacher, and others in the surroundings have both to the language or languages that should be learned and to the child who should learn, are also critical for success in language development. Also significant are the teachers' competence and training, the quality of the activity in the preschool, and if the teachers work with language development (Ministry for Education and Research, 2006). Through the teachers' acceptance of diversity, the language support work, the collaboration of different teacher categories, and the native language supporters who speak the same language as the parents, the children in preschool can have the opportunity to expand their vocabulary and use the language they speak at home.

\section{Participation Conditions and Opportunities in Life}

Within the preschool program, there are thus opportunities to develop both native language and multilinguistic affiliation. Capability in the native language appears as a linguistic richness that is good for the children's learning, education, development, and life (Education Department, 2011). From the policies, we can also understand that a rich and varied language is a prerequisite for being able to understand and work in a society where cultures, world views, generations, and languages meet. A linguistic richness appears as a condition for participation and opportunities in life.

Research shows that different languages and multilingualism, however, are sometimes expressed as something different. Linguistic diversity and multilingualism are expressed instead, as somewhat problematic both in the school and in the preschool pedagogical practice (Lahdenperä, 1997; Torpsten, 2008).

If we speak about the children in preschool with a native language other than Swedish as being both less knowledgeable and more problematic than their Swedish-speaking peers, then we will create superiority/super-ordination and inferiority/subordination (Fanon, 1971). And when the inferior children are reflected in the superior teachers' and children's expectations of them, their identity is created as subordinate. Children who have a native language other than Swedish can be considered as the other, the less capable in relation to us or we (who speak Swedish), because they cannot express their thoughts, knowledge and, feelings in the preschool language which is Swedish. Mastering a language means an enormous power and that power can be exercised over those who have not mastered the language. For example, we who master the language 
that is spoken by the majority rule the world that we express by means of the language. We have the privilege of interpretation. For a child, not to be able to express oneself or not to have access to the preschool language can be stated as not to be present or not to exist (Fanon, 1971) for the other children or for the teachers. It can also be stated as not having the key to the preschool language-room. In this existence of not being present and of lacking the key, low expectations of the child and obstacles are created instead of opportunities. A key to the closed language-doors and to opportunities and high expectations can be skills in the preschool language, Swedish. Fluency in the native language and high expectations for multilingualism mean being present in a native language and multilingual context. The native language thus can be the key that opens doors and creates opportunities that are active in a global society, that is to say, increased participation chances in a world-wide context.

The exercise of power and access to different languages can be also spoken of as access to various social and cultural capitals. Education, adaptation, and increased cultural capital make it possible for people to raise their social positions (Bourdieu, 2005). When a child in the preschool pedagogical practice both develops his or her native language and learns the school language, it means that the social and cultural capital increases. The child becomes less subordinate, can play together in many settings and get access to the world in the preschool and in the society that is expressed and understood through language.

\section{Conclusion}

With my presentation, I have shown that the concepts of power and linguistic arenas or linguistic contexts (Cummins \& Schecter, 2003; Fanon, 1971; Petersson \& Åhlund, 2007a, 2007b) can be helpful when we are to understand the curriculum statements and the preschool pedagogical practice. In the preschool pedagogical practice, all children can learn to use several new language keys (Fanon, 1971) with the help of a language development approach. In this way, they can also take control over both the preschool language and the native language. They become less subordinate and gain good chances to participate, to co-exist, and to learn in both the preschool arena and other contexts (Fanon, 1971; Milani, 2007). My discussion reveals that co-existence in the preschool may be possible when the children, for example through native language support in preschool, are given opportunities to develop their native language. When they also master the preschool common language, Swedish, co-existence becomes further possible.

Knowledge in several languages also makes it possible for all children to learn from each other. In this context, a language development approach means allowing all children, perhaps with help, to read to their classmates in their native language. The books may be in common, but in different languages or in one language where someone or some children can tell the story in Swedish, which is the common language afterwards.

In conclusion, it would be interesting to discuss how many there are whose language is spoken and read by children and read by the native language instructors for the children at different preschools. One question is about which knowledge and skills are shared between the children and the native language instructors. Other questions of interest in this context are how the native language instruction is organized, how the teaching teams promote language, and how the instruction contributes to benefiting multilingualism and diversity for all children. 


\section{References}

Ahlstedt, K. (2014). Skolbibliotekarier i världsklass (School librarians of world class). Malmö: Pedagog Malmö. Retrieved from http:/webapps2.malmo.se/pedagogmalmo/2014/03/03/skolbibliotekarier-i-varldsklass/

Benhabib, S. (2004a). Jämlikhet och mångfald. Demokrati och medborgarskap i en global tidsålder (Equality and diversity. Democracy and citizenship in a global era). Göteborg: Daidalos.

Benhabib, S. (2004b). The rights of others. Cambridge: Cambridge University Press.

Bourdieu, P. (2005). Praktiskt förnuft. Bidrag till en handlingsteori (Practical sense. Contributions to an action theory). Göteborg: Daidalos.

Creese, A., \& Blackledge, A. (2010). Translanguaging in the bilingual classroom: A pedagogy for learning and teaching. The Modern Language Journal, 94(1), 103-115.

Cummins, J. (2006). Foreword. In P. Gibbons (Ed.), Stärk språket stärk lärandet (Strengthen language strengthen learning). Stockholm: Fallgren \& Hallgren.

Cummins, J. (2007). Rethinking monolingual instructional strategies in multilingual classrooms. Canadian Journal of Applied Linguistic (CJAL), 10(2), 221-238.

Cummins, J., \& Persad, R. (2014). Teaching through a multilingual lens: The evolution of EAL policy and practice in Canada. Education Matters, 2(1), 3-40.

Cummins, J., \& Schecter, S. R. (2003). School based language policy in cultural diversity contexts. In S. R. Schecter and J. Cummins (Eds.), Multilingual education in practice: Using diversity as a resource. Portsmouth: Heinemann.

Ekberg, J., \& Roth, D. O. (2000). Arbetsmarknadspolitik för invandrare. Rapport till riksdagens revisorer (Labor market policy for immigrants. Report to Parliamentary Auditors) 2000/6. Växjö: Växjö universitet (Växjö University).

Fanon, F. (1971). Svart hud, vita masker (Black skin, white masks). Göteborg: Daidalos.

García, O. (2012). Theorizing translanguaging for educators. In C. Celic and K. Seltzer (Eds.), Translanguaging in the bilingual classroom: A pedagogy for learning and teaching? Modern Language Journal, 94(1), 103-115.

Hyltenstam, K. (1988). Att tala svenska som en infödd eller nästan (Speaking Swedish as a native or nearly). In K. Hyltenstam and I. Lindberg (Eds.), Första symposiet om svenska som andra språk (First symposium on Swedish as a second language) (Vol. I). Stockholm: Centrum för tvåspråkighets forskning (Centre for bilingual research): Stockholms universitet.

Hyltenstam, K., \& Tuomela, V. (1996) Tvåspråkighet med förhinder? Invandrar-och minoritetsundervisning i Sverige (Bilingualism having prevented? Immigrant and minority education in Sweden). In Hemspråksundervisningen (Mother tongue teaching). Lund: Studentlitteratur.

Lahdenperä, P. (1997). Invandrarbakgrund eller skolsvårigheter? En textanalytisk studie av åtgärdsprogram för elever med invandrarbakgrund (Immigrant background or school difficulties? A textual analysis study of intervention programs for pupils with immigrant background). Stockholm: HLS Förlag.

Lindberg, I. (2002). Myter om tvåspråkighet (Myths about bilingualism). Språkvård (Language care), (4)2002. Stockholm: Språknämnden (Language Board).

Lunneblad, J., \& Asplund Carlsson, M. (2009). De komma från nordost. Om skolkonkurrens och elevidentitet i ämnet svenska som andraspråk (They come from the northeast. School competition and pupil identity in the subject Swedish as a second language). Utbildning och Demokrati (Education and Democracy), 18(2), 97-103.

Milani, T. (2007). Debating Swedish. language politics and ideology in contemporary Sweden. Stockholm: Stockholms Universitet (Stockholm University).

Myndighetenförskolutveckling (Ministry for Education and Research). (2006). Komma till tals (Have one's say). Stockholm: Myndighetenförskolutveckling (Ministry for Education and Research).

Myndighetenförskolutveckling (The Ministry for Education and Research). (2006). Komma till tals (Be heard). Stockholm: Myndighetenförskolutveckling (The Ministry for Education and Research).

Peterson, A., \& Åhlund, A. (2007a). Etniciteter: Ras, kön, klass, identitetochkultur (Ethnicities: Race, gender, class, identity and culture). In A. Peterson and M. Hjerm (Red.), Etnicitet. Perspektiv på samhället (Ethnicity. Perspectives on society). Malmö: Gleerups Förlag.

Peterson, A., \& Åhlund, A. (2007b). Ungdomar och identitet (Adolescents and identity). In A. Peterson and M. Hjerm (Red.), Etnicitet. Perspektiv på samhället (Ethnicity. Perspectives on society). Malmö: Gleerups Förlag.

Petersson, A., \& Åhlund, A. (2007a). Ungdomar och identitet (Youth and identity). In A. Peterson and M. Hjelm (Eds.), Etnicitet. Perspektiv på samhället (Ethnicity. Perspective on society). Malmö: Gleerups. 
Petersson, A., \& Åhlund, A. (2007b). Ungdomar och identitet (Youth and identity). In A. Peterson and M. Hjerm (Eds.), Etnicitet. Perspektiv på samhället (Ethnicity. Perspective on society) (pp. 186-193). Malmö: GleerupsFörlag.

Proposition. (1975/76:39). Om skolans inre arbete (School's inner work). Stockholm: Regeringskansliet (Government Council, 1975).

Proposition. (1975:26). Om riktlinjer för invandrar-och minoritetspolitiken (Guidelines for immigrant and minority policy). Stockholm: Regeringskansliet (Government Council, 1975).

Proposition. (1997/98:16). Sverige, framtiden och mångfalden-från invandrarpolitik till integrationspolitik (Sweden, the future and diversity - From immigrant policy to integration policy). Stockholm: Regeringskansliet (Government Department).

Regeringskansliet (Government Department). (1975). Om riktlinjer för invandrar-och minoritets politiken (Guidelines for immigrant and minority policy). Proposition 1975:26. Stockholm: Regeringskansliet (Government Department).

Runfors, A. (2003). Mångfald, motsägelser och marginaliseringar. En studie av hur invandrarskap formas $i$ skolan (Diversity, contradictions and marginalization. A study of how being an immigrant is formed in school). Stockholm: Prisma.

Skollagen (School law). (2010). Skollagen 8 kap (School law, 8). Förskolan 10§ (Preschoo 10§). Stockholm: Norstedts Juridik.

Skolöverstyrelsen (Swedish National Board of Education). (1973). Lgr69, Läroplan för grundskolan. Supplement. Undervisning av invandrarnas barn $m f l-2$ (Curriculum for compulsory school. Supplement. Instruction of immigrant and other children). Stockholm: Skolöverstyrelsen (Swedish National Board of Education).

Skolverket (National Agency for Education). (2008). Läroplan för förskolan (Curriculum for preschool), Lpfö. Stockholm: Skolverket (National Agency for Education).

Skolverket (National Agency for Education). (2011). Läroplan för förskolan (Curriculum for preschool), Lpfö. Stockholm: Skolverket (Swedish National Agency for Education).

Skolverket (Swedish National Agency for Education). (2002). Flera språk - fler möjligheter - utveckling av modersmålsstödet och modersmålsundervisningen (More languages - More opportunities - Development of mother tongue support and mother tongue education). Stockholm: Skolverket (Swedish National Agency for Education).

Skolverket (Swedish National Agency for Education). (2010). Läroplan för förskolan (Curriculum for preschool), Lpfö. Stockholm: Skolverket (National Agency for Education).

SOU. (1972:26). Förskolan 1. Betänkande angivet av 1968 års barnstugeutredning (Preschool 1. Report on the 1968 Children's Preschool Review). Stockholm: Utbildnings departementet (Education Department).

SOU. (1974:53). Skolans arbetsmiljö. Betänkande. Utredningen om skolans inre arbete (The school work environment. Report. Review of the school's inner work). Stockholm: Utbildnings departementet (Education Department).

SOU. (1974:69). Invandrarutredningen 3. Invandrarna och minoriteterna. Huvudbetänkande från invandrarutredningen (Immigrant review 3. Immigrants and minorities. Main report from the immigrant review). Stockholm: Arbetsmarknads departementet (Labour Department).

Svensson, G., \& Torpsten, A. C. (2013). Synligt och osynligt i individuella utvecklingsplaner (Visible and invisible in individual development plans). In J. A. Chrystal and M. Lim Falk (Eds.), Tionde nationella konferensen i svenska med didaktisk inriktning. Genre. Texter om svenska med didaktisk inriktning (Tenth National Conference on Swedish Didactics. Genre. Texts on Swedish Didactics) (pp. 139-158). Nationella nätverket för svenska med didaktisk inriktning (National Network for Swedish Didactics): Stockholms Universitet (Stockholm University).

Torpsten, A. C. (2008). Erbjudet och upplevt lärande i mötet med svenska som andraspråk och svensk skola (Offered and experienced learning in meeting Swedish as a second language and the Swedish school). Växjö: Växjöuniversitet (Växjö Universdity).

Torpsten, A. C., \& Betzholtz, M. (2013). Preschool-A diverse and multilingual arena. The International Journal of Education for Diversities. E-tidskrift, 2013(2), 1-21.

Utbildningsdepartementet (National Agency for Education). (2011). Läroplan för grundskolan, förskoleklassen och fritidshemmet 2011. Kursplan i modersmål (Curriculum for compulsory school, kindergarten and after-school program 2011. Syllabus for mother tongue). Stockholm: Utbildningsdepartementet (National Agency for Education). 